\title{
BULGARIAN RENEWABLE ENERGY IN THE CONTEXT OF THE CONTEMPORARY TRENDS
}

\author{
Maria Kotseva-Tikova ${ }^{1}$ \\ Sofia University (Bulgaria)
}

\begin{abstract}
The aim of the article is to analyze the results of the Bulgarian renewable energy policy in the context of the EU aims and global renewable energy system (RES) investments till 2014. The policy is examined through comparison of the aims as stated in the National Renewable Energy Action Plan (NREAP) of Bulgaria and the achieved results. They are evaluated in respect of renewables share in final energy consumption, greenhouse gas emissions, and household access to green energy sources. The main outcomes show a low level of decentralized energy generation and pressure upon electricity price increase.

KEY WORDS: Bulgaria, energy, climate changes, policy, renewable energy sources, investments.
\end{abstract}

JEL CODES: Q48, Q42, Q54

\section{Introduction}

Growth is the most important aim of the economic policy, which will lead to national wealth, employment, income and profits. It is turned into credo and sometimes is accompanied by unconditional admiration. Few people are satisfied with what they have at present, most want more. The constant increase of consumption and production is an indicator for the successful development of each country. For over 200 years different economists have tried to answer the questions whether it is possible to have constant growth and whether it lead to better living conditions. Many countries face enormous ecologic problems and negative climate impacts, which accompany their growth.

The climate changes are result of natural and anthropological factors. While the main natural factors as solar radiation changes, continents movements, volcanos and ocean streams are not under the human control, the anthropological factors are and need to be addressed. The international community has already recognized the increasing impact of the anthropological activity upon climate. This activity has resulted in significant temperature changes. The global average temperatures have risen with $0,74{ }^{\circ} \mathrm{C}$ during the period 1904-2005. The scientists have proved that human activity and mainly the energy and cement sectors have contributed to greenhouses increase lately. That threatening results force the states act globally and jointly in applying measures to decrease greenhouse emissions and to accept a global agreement for coordinated efforts to cope with the problem. The EU is firmly engaged with the cause and sees green energy as a possible instrument for cleaner environment. The union has elaborated plans with necessary actions in the field of energy efficiency increase, broader RES adoption and emissions decrease till 2030 and a roadmap to 2050.

1 Maria Kotseva-Tikova - lecturer at the Sofia University, Bulgaria and a researcher at the Institute of Economic Analyses at the Bulgarian Academy of Sciences

Scientific interests: RES policy development and implementation, as well as public finance

E-mail: maria_kotseva@yahoo.com

Tel. +359895792982 
The aim of the present report is to analyze the Bulgarian renewable energy policy in the context of the EU aims and the contemporary global ecological and investment trends. The policy results are examined through comparison with the targets as stated in the National Renewable Energy Action Plan (NREAP) of Bulgaria. They are evaluated in respect of renewables share in final energy consumption, the energy structure, greenhouse gas emissions, and household access to green energy sources.

In 2012 Bulgaria overfilled its renewable energy aim of $16 \%$. The country became one of the three states, which have exceeded their 2020 final target in 2012. Sweden and Estonia are the first two countries that overfilled their aim in 2011.

This success has not provided the households with affordable energy supplies and has resulted in unacceptance and negative attitudes towards the green electricity because of the vicious practices in the realization of such projects. The state has missed to obtain positive economic results from the expansion of RES investments.

The methodology applied in the present research is dynamic and sector analyses of the main energy indicators, investment trends and financial flows in RES as well as greenhouse emissions.

\section{Climate Changes and the European Policy for Res}

All we need is growth. The famous refrain could be transformed in order to describe the modern economic aim. Of course the growth is necessary but it is not the only factor for welfare increase. It is turned into credo and sometimes is accompanied by unconditional admiration. But we still face the questions: is it possible to have constant growth and does it lead to better living conditions. Since the 70 -ies of XX century growth criticisms have increased inspired by ecological and social factors. New theories and models have been developed in order to explain the new visions for economic development, as all of them have been inspired by the need to decrease the negative human impact and avoid serious climate changes.

The climate changes are result of natural and anthropological factors. The main natural factors are solar radiation changes, continents movements, volcanos and ocean streams, which cannot be controlled by man. They can change the quantity of the solar radiation, the emitted greenhouse gasses as $\mathrm{CO}$, $\mathrm{CH} 4$ and $\mathrm{N} 2 \mathrm{O}$, and as a result to make the average temperature rise. The anthropological factor is the one that has gained threatening dimensions and is subject to human control. The international community has already recognized the increasing impact of the anthropological activity upon the climate.

According to the Global Carbon Budget (2015) "Total cumulative emissions from 1870 to 2014 were $400 \pm 20 \mathrm{GtC}(1465 \mathrm{GtCO} 2)$ from fossil fuels and cement, and $145 \pm 50 \mathrm{GtC}(549.6 \mathrm{GtCO} 2)$ from land use change. The total of $545 \pm 55 \mathrm{GtC}$ was partitioned among the atmosphere $(230 \pm 5 \mathrm{GtC})$, ocean $(155 \pm 20$ $\mathrm{GtC})$, and the land $(160 \pm 60 \mathrm{GtC})$ ". The growth of the global CO2 emissions from the burning of fossil fuels and the manufacture of cement for the period 2006-2011 is rising, reaching $34649483 \mathrm{kt}$ (Figure 1).

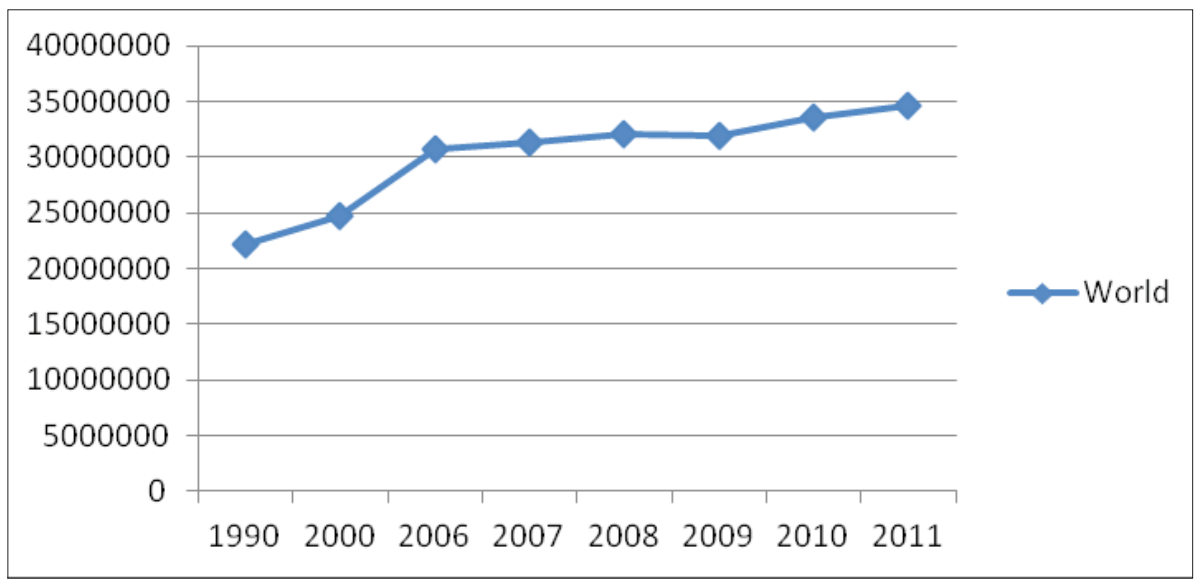

Figure 1. Carbon dioxide emissions from the burning of fossil fuels and the manufacture of cement in the world (kt) Source: World Bank Database 
In 2011 the emissions reached levels that are higher by over $50 \%$ than the levels in 1990. And this is a result of the intense adoption and utilization of fossil fuels. Over $50 \%$ of these emissions were emitted by three countries - China, the USA and India (Figure 2).

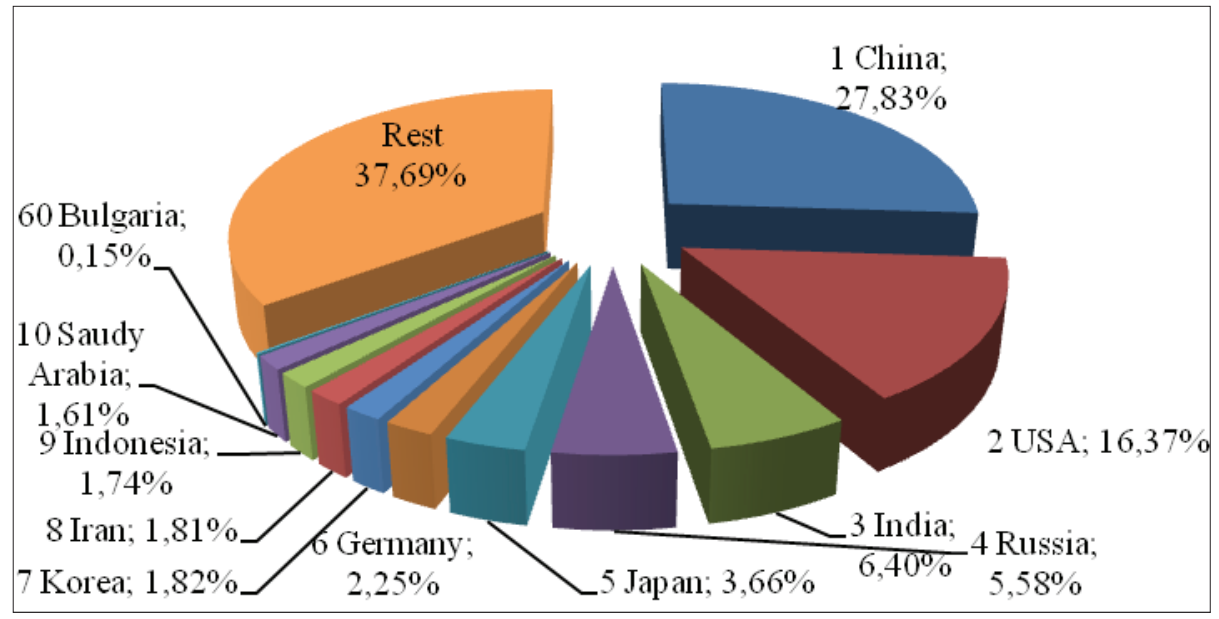

Figure 2. Top $10 \mathrm{CO}_{2}$ emitters in 2011

Source: World Bank Database

The European Union had a share of $9.2 \%$ of the emissions in 2011, which ranked it third in the world. Bulgaria was on the 60-th position in the world and on the 16-th among the EU member states. It emitted $0.15 \%$ from the worlds' emissions and $1.55 \%$ from the ones of the EU.

Most of the emissions were $\mathrm{CO}_{2}$ emissions and a result from coal and oil burning. The modern economy and households depend on the conventional energy generation. The economic growth is subject to increasing use of electricity and oil for the transport. In 1896 the Swedish scientist Svante August Arrhenius defined the concept of greenhouse gas effect and estimated that the doubling of the $\mathrm{CO}_{2}$ concentration, which a result of coal burning, could raise the average global temperature with $3-5{ }^{\circ} \mathrm{C}$. The global average temperatures have risen with $0,74{ }^{\circ} \mathrm{C}$ during the period $1904-2005$. Three independent long records of global average near-surface (land and ocean) annual temperature show that the decade between 2005 and 2014 was $0.80{ }^{\circ} \mathrm{C}$ to $0.84{ }^{\circ} \mathrm{C}$ warmer than the pre-industrial average (EEA, 2016). The scientists have proved that the considerable greenhouses increase lately is a result of the human activity and mainly the energy and cement sectors. They have developed models in order to prove the relation between the temperature changes and the $\mathrm{CO}_{2}$ emissions from the human activity. The global community has been looking for mechanisms to make the nations work jointly in order to keep the temperature rice under $2{ }^{\circ} \mathrm{C}$. After the Kyoto Protocol from 1997 the climate change conference in Paris in 2015 adopted a global agreement for joint efforts for global worming reduction. The EU participated actively and supported the initiative for global measures against climate changes.

The Union was ranked 3-d globally in respect of the greenhouse gas emissions and it is actively searching and elaborating mechanisms to change its energy resource base in order to decrease the negative impact upon the climate. Initially the EU was established with the aim to develop the energy sector jointly. The European energy policy is still the joining unit which has been developed and enriched till now. Part of the energy policy is the aim of the RES development.

The EU aim is to have a $20 \%$ share of renewable energy in the final energy consumption and a $10 \%$ share of biofuels in 2020. The target is defined in the Directive 2009/28/EC of the EP and EC from 23.4.2009. This document has replaced the Directive 2001/77/EC and has defined concrete targets for each member state, as well as it has stipulated the obligation for the establishment of a National Renewable Energy Action Plan. The EU envisages expanding the application of RES as a mechanism for sustainable development, because they are inexhaustible, clean, provide independent and decentralized generation, and create jobs. Renewa- 
bles do not create outer negative effects which incur social costs. This is the case of the burning of coal and oil which causes $\mathrm{CO}_{2}$ emissions and imposes outer costs for the society.

RES are important mean for climate friendly energy generation but also for coping with the main world problem - the energy price volatility and namely the oil price. The energy independence is an important priority of the EU energy policy.

The oil production is concentrated in a certain regions and the oil producing countries define the production quantity in order to control the price. The industry and the transport depend highly upon oil, which determines a strong political risk for the energy supply as well as for the economic development. Renewables are a possible factor for minimization of the risk of price volatility of fossil fuels and of the political risk. Awerbuch (2007) describes them as "a form of national insurance, which pays back in terms of bad economic years". In 2014 the energy dependency of the EU-28 is $53.5 \%$, as petroleum fuels have the highest import dependence of $87.4 \%$. Bulgaria has a lower ratio of $34.5 \%$. According to Awerbuch (2006) each consumer of fossil fuels can hedge the price risks but the total society cannot. The price risk of oil and gas can be transferred to organizations capable of managing the risk, but it cannot be fully eliminated. RES could be the instrument for such minimization. From a microeconomic point of view RES decrease the costs of generation and the risk, because their prices do not change simultaneously with the change of the fossil fuels prices. The diversification of the energy portfolio can result in higher returns under optimal risk.

From a macroeconomic point there is a relation between the oil price change and the gross national product. If the price of the oil increases the economy shrinks. This effect cannot be diversified through RES contribution.

Renewables allow energy supply to places with difficult access. The technology for wind and PV generation creates decentralized supply. Energy decentralization is an important instrument for energy efficiency and energy dependency decrease. Households and medium and small-sized enterprises (MSP) can obtain benefits of such decentralization, which make them competitive and enhance the living comfort of people. Thus the green technologies spur innovations development, investments and employment creation. All their positive aspects change the economic base of the modern society and are in the base of the movement for sustainable and green economy. The EU strategy for development till 2020 stipulates and requires such a development through low-carbon energy. It elaborates obligations for the member states as well as provides financing in order to help the members to realize the benefits from such a policy. The policy evolves and in 2030 the EU forecasts a $40 \%$ decrease of emissions compared to 1990. Such a purpose requires RES share to become $27 \%$ in the final energy consumption as well as a $27 \%$ energy efficiency increase. The EU tries to find flexible measure for the national energy sector management, as they are synchronized and make the economic foreseeable.

The path for the future development is clear - decrease of the energy consumption through efficiency and more renewable energy supply. The society needs energy transformation and establishment of stable production and consumption patterns to balance the three systems: environmental, economic and social. The green growth strategies could bring ecological and economic benefits, but they are not a panacea for economic troubles solving. In the short run they create costs but in the long run - create benefits and sustainable growth.

\section{New Investments in Res}

In 2015 the new investments in RES reached $\$ 285.9$ billion and it exceeded the previous year amount by $5 \%$. It is the highest amount for a period of 12 years (2004-2015) according to Bloomberg (UNDP, 2015). They retain their ascending trend despite the global GDP decrease (table 1). 
Table 1. New RES Investments Share

\begin{tabular}{|l|l|l|l|l|l|c|}
\hline \multicolumn{1}{|c|}{ Index } & \multicolumn{1}{|c|}{2010} & \multicolumn{1}{|c|}{2011} & \multicolumn{1}{|c|}{2012} & \multicolumn{1}{c|}{2013} & \multicolumn{1}{c|}{2014} & \multicolumn{1}{c|}{2015} \\
\hline World GDP (\$ BN) & 65647.82 & 72843.14 & 74428.36 & 76431.32 & 78106.34 & 73433.64 \\
\hline $\begin{array}{l}\text { New RES Investments in GDP } \\
(\%)\end{array}$ & $0.36 \%$ & $0.38 \%$ & $0.35 \%$ & $0.31 \%$ & $0.35 \%$ & $0.39 \%$ \\
\hline Rate of new investment (\%) & $33.9 \%$ & $16.4 \%$ & $-7.6 \%$ & $-9.1 \%$ & $16.7 \%$ & $4.7 \%$ \\
\hline Rate of world GDP (\%) & $4.3 \%$ & $3.1 \%$ & $2.5 \%$ & $2.4 \%$ & $2.6 \%$ & $2.5 \%$ \\
\hline
\end{tabular}

Sources: World DataBank: www.worldbank.bg; UNDP, 2015. Global Trends in Renewable Energy Investments; author's calculations.

In 2015 the world GDP decreased under the 2012 level and the global economy maintains growth rate of $2.5 \%$, while the RES investments increased. Renewables share in GDP reached the level of $0.39 \%$, which is the highest value for the last 12 years.

The sector analysis of RES (figure 3) shows that since 2012 solar energy has attracted the highest investment amounts. The ascending trend was retained till 2015, when $56 \%$ of the investments were in solar technologies. The increase is over 12 times above the investments level in 2004. On the second place in respect to attracted new investments and growth is the wind energy.

The geographic distribution of the financial flows shows that Europe is a leader with the highest investments in RES till 2012 (figure 4). In 2013 it conceded the first rank with investments at $\$ 60$ billion. Since 2013 Chine has gained the first position with investments of $\$ 62$ billion in 2013, $\$ 87.8$ billion in 2014 and $\$ 102.9$ billion in 2015. The third position if for Asia (excluding China and India) and the Pacific. There is an unprecedented growth of PV installations in China and Japan.

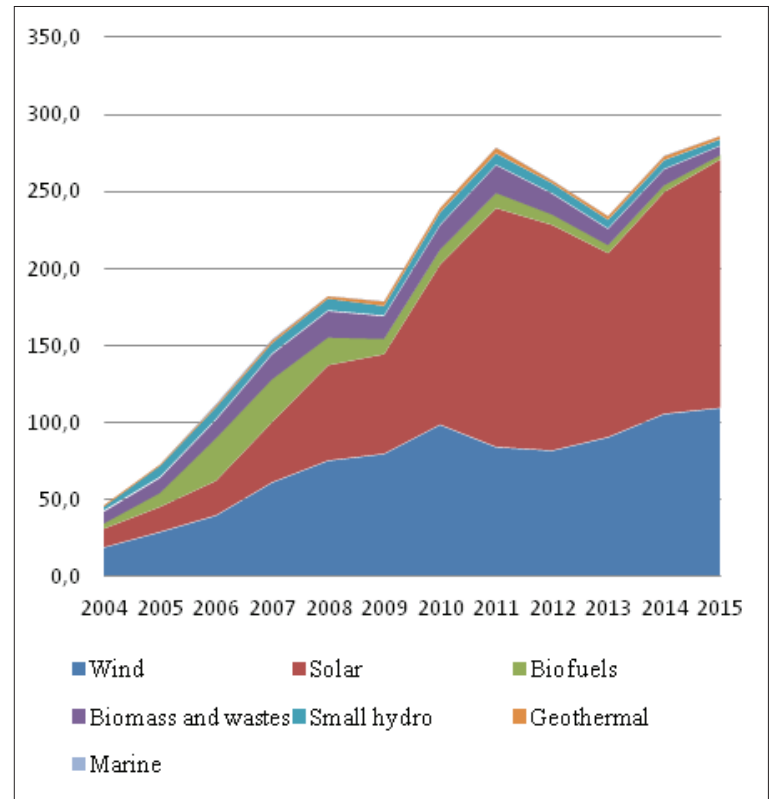

Figure 3. New Investment by Sector (\$ BN)

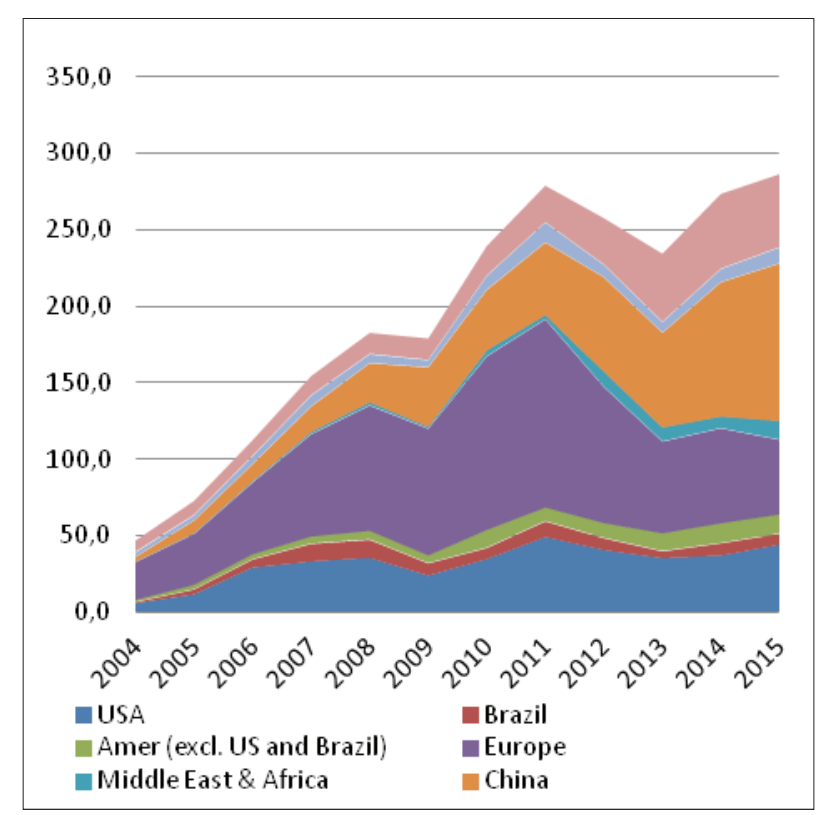

Figure 4. New Investment by Geography (\$ BN)

Sources: UNDP, 2105; Global Trends in Renewable Energy Investments, p. 15

The RES investments in Europe peaked in 2012 and during the last 3 years they have decreased, as in 2015 they were $40 \%$ of the investments in 2012 (Figure 5). 


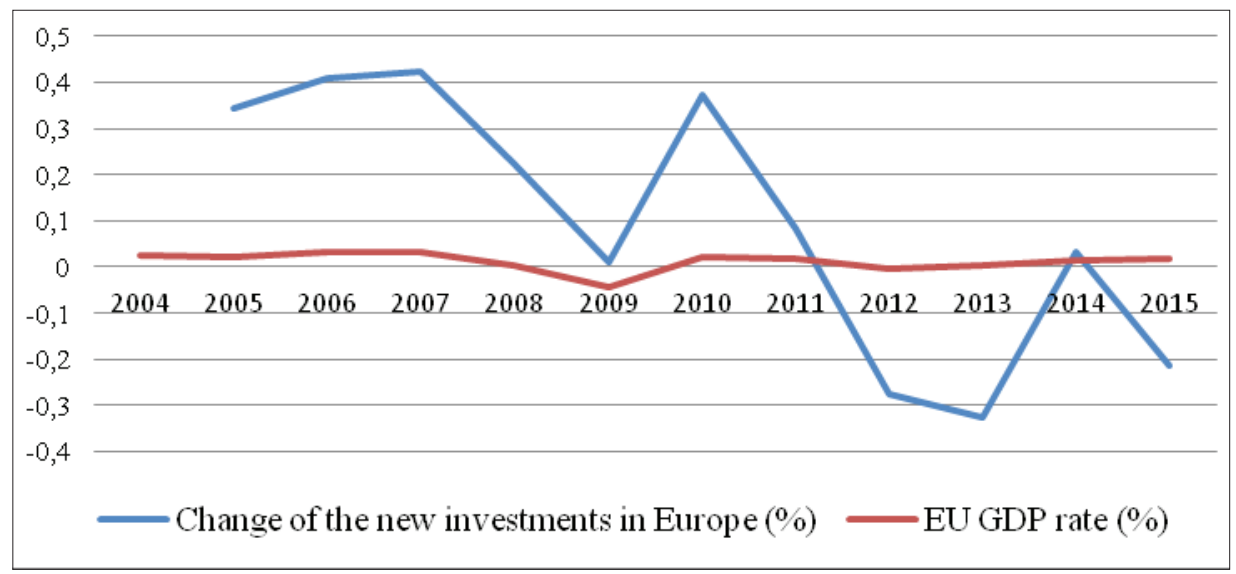

Figure 5. RES Investment Change in Europe

Sources: World DataBank, Available at: www.worldbank.bg, author's calculations.

The drop of RES investments after 2011 corresponds to the weak performance of the EU economy, which recovers slowly after the global finance and economic crisis. Such a decrease in the region that is the most active supporter of the green energy is compensated by a strong growth in countries as China and Japan. The notion that the alternative energy sources are suitable only for rich countries is disproved by the financial flows of 2015. For a first time developing countries have invested more than the developed $-\$ 156$ billion against $\$ 130$ billion. Around $\$ 120$ billion are the investments in China, India and Brazil (UNDP, 2015). The developing countries are active in solar and wind energy as wind energy is preferred. While the investment amounts in solar technologies are equal in the developing and developed countries, the developing have invested $50 \%$ more in wind. They have made more investments in small hydro and geothermal energy. The developed have realized more projects for biomass and wastes, biofuels and marine.

In 201510 countries realized 85\% of the RES investments (table 2).

Table 2. Top 10 Countries with New Investments in RES in 2015

\begin{tabular}{|l|l|}
\hline \multicolumn{1}{|c|}{ Country } & \multicolumn{1}{c|}{ \$ Billion } \\
\hline China & 102.9 \\
\hline USA & 44.1 \\
\hline Japan & 36.2 \\
\hline GB & 22.2 \\
\hline India & 10.2 \\
\hline Germany & 8.5 \\
\hline Brazil & 7.1 \\
\hline South Africa & 4.5 \\
\hline Mexico & 4.0 \\
\hline Chilly & 3.4 \\
\hline
\end{tabular}

Sources: UNDP, 2105; Global Trends in Renewable Energy Investments, p. 23

In 2015 asset finance was the main investment type, followed by the small distributed capacities and public markets for equipment manufacturing. In Japan over $87 \%$ of the projects were small distributed capacities, in the USA they were $20 \%$, in China $-5 \%$, in GB $-8 \%$. In Europe under $3 \%$ was the share of small distributed capacities, as over $50 \%$ of the investments were wind projects and $1 / 3$ - solar energy. The wind projects were realized through asset finance (95\% of the invested amounts) and the rest was small distributed capacities, and R\&D. The solar energy was financed mainly through the public markets ( $2 / 3$ of the flows), as well as asset finance and R\&D. The rest RES were realized through asset finance mainly. 
The global public market investments decreased and amounted at $\$ 12.8$ billion in 2015. The IPOs contracted to $18 \%$ of the investments, secondary issues and private investment in public equity had a share of over $50 \%$. The R\&D costs stayed at the level of 2014 . The Governmental R\&D slightly decreased as they were compensated by an increase of the corporate. In 2015 the R\&D in Europe drop in comparison with the previous year and reached a level of $\$ 2.8$ billion. China had such a level too, as during the last years the country has been increasing the investments with priority solar efficiency improvement, which has turned it into a leader among the solar technology producers.

In 2015 the new RES investments in Europe were a result of projects in GB and Germany. Almost half of the investments have been realized in GB - \$22.2 billion mainly in big offshore wind farms. Germany holds a second position with $\$ 8.5$ billion, as this is the lowest amount for the last 12 years. The wind energy decreases because of the uncertainty resulting from the change of the support mechanisms - transition from feed in tariffs to tenders. Similar untrustworthiness resulting of the decreased feed in tariffs leads to investment stagnation in France. In Italy and Spain the retroactive price diminishing shrinks the investment flows too.

\section{Renewable Energy Policy of Bulgaria}

The Bulgarian energy policy is developed and conducted in compliance with the Energy Law of the country. The policy is realized through an Energy Strategy developed by the Council of Ministers (CM) and adopted by the National Assembly. CM governs the energy sector in compliance with the Energy Strategy. In 2015 a new Ministry of Energy was established which emphasized the priority of the energy policy for the country. The Minister of Energy is a key player in the process of energy policy creation, as well as future RES development.

As a member of the EU, Bulgaria has to adopt all the regulations and obligations concerning energy, respectively renewables. The country has elaborated an Energy strategy for 2020 describing the main ways for development of the sector with emphases on RES deployment and energy efficiency measures implementation. The country prepared a National Renewable Energy Action Plan (NREAP) concerning the pathway for the fulfillment of the national target, as defined in the Directive 2009/28/EC. It was elaborated in correspondence with the Directive and adopted in January 2013. The NREAP purpose is to have a $16 \%$ share of RES in the final energy consumption and a $10 \%$ share of renewables in transport in 2020 . The expected results from such a policy are: "Minimization of pollution and provision of new business opportunities - through higher efficiency and stimulation of new technologies for the rapidly developing global market, from decreasing the energy consumption to safe, diverse and cheap energy supply."

The compulsory character of the national RES obligation requires each member state to declare its achievements every 2 years. Presently three reports have been prepared - at the end of 2011, 2013 and 2015 with information about the performance during 2009-2010, 2011-2012, and 2013-2014 respectively. Most of the countries achieve or go beyond their national renewables target for RES share for each year. Table 3 shows the fulfillment of the interim targets of EU member states.

During the observed 5-year period 17 member states have achieved or gone beyond the national renewables targets. In 2014 their number was 21 of the states that met their interim aim, as the highest fulfillment was performed by Croatia - 11,5 percent points higher than the annual target, followed by Bulgaria -6.62 percent points, Italy -6.58 percent points, Finland -6.5 percent points and Sweden -6.3 percent points. Nine countries have achieved RES shares higher than their 2020 aim and Bulgaria is among them. In 2012 Bulgaria achieved $16 \%$ RES share, which is its final aim. Sweden and Estonia also overfilled their 2020 aim an year earlier - in 2011 and presently they continue to increase the green energy in their national energy mix. The Netherlands and Ireland have e weak performance, as during the whole period they go beneath the target levels. Spain, France, Cyprus, Malta, Austria, Portuguese, Poland and Slovakia do not fulfill their target during some of the years. 
Table 3. Level of Fulfillment of the Interim RES Targets of EU-28

\begin{tabular}{|l|l|l|l|l|l|}
\hline \multicolumn{1}{|c|}{ Member State } & \multicolumn{1}{c|}{2010} & \multicolumn{1}{c|}{2011} & \multicolumn{1}{c|}{2012} & \multicolumn{1}{c|}{2013} & \multicolumn{1}{c|}{2014} \\
\hline Belgium & 1.70 & 1.80 & 2.00 & 1.70 & 1.20 \\
\hline Bulgaria & 4.04 & 3.58 & 5.28 & 7.62 & 6.62 \\
\hline Czech Republic & 1.20 & 0.10 & 1.30 & 1.60 & 2.10 \\
\hline Denmark & 0.20 & 0.10 & 1.40 & 0.00 & 2.00 \\
\hline Germany & 0.40 & 0.60 & 0.70 & 0.40 & 1.00 \\
\hline Estonia & 3.70 & 4.30 & 3.80 & 2.30 & 3.10 \\
\hline Ireland & -1.00 & -0.10 & -0.50 & -0.90 & -0.50 \\
\hline Greece & 1.80 & 2.10 & 3.90 & 5.10 & 4.80 \\
\hline Spain & 0.20 & -1.00 & -0.50 & -0.10 & -0.30 \\
\hline France & 0.10 & -2.40 & -0.60 & -1.00 & -1.70 \\
\hline Croatia & 11.80 & 11.20 & 11.70 & 12.30 & 11.50 \\
\hline Italy & 4.95 & 4.25 & 6.17 & 6.84 & 6.58 \\
\hline Cyprus & -0.50 & -0.80 & -0.30 & 0.30 & 0.60 \\
\hline Lithuania & -2.30 & -0.30 & 1.40 & 2.40 & 3.70 \\
\hline Latvia & 3.80 & 3.20 & 3.70 & 4.00 & 3.90 \\
\hline Luxemburg & 0.70 & 0.00 & 0.20 & -0.30 & 0.60 \\
\hline Hungary & 1.20 & 1.80 & 2.20 & 2.00 & 1.50 \\
\hline Malta & -0.70 & -0.40 & 0.30 & -0.10 & -0.70 \\
\hline Netherland & -0.30 & -0.10 & -0.90 & -1.80 & -2.20 \\
\hline Austria & -0.50 & -0.60 & 0.00 & 0.50 & 1.00 \\
\hline Poland & -0.38 & 0.21 & 0.30 & 0.25 & -0.05 \\
\hline Portugal & 0.10 & -0.50 & -1.90 & -1.40 & -0.40 \\
\hline Romania & 5.90 & 3.40 & 3.76 & 4.55 & 5.24 \\
\hline Slovenia & 2.80 & 2.00 & 2.20 & 3.00 & 1.80 \\
\hline Slovakia & -0.40 & 2.10 & 2.20 & 1.20 & 2.70 \\
\hline Finland & 3.70 & 2.70 & 3.40 & 5.10 & 6.50 \\
\hline Sweden & 3.70 & 4.80 & 6.20 & 6.40 & 6.30 \\
\hline UK & 0.70 & 0.20 & 0.60 & 0.60 & 1.00 \\
\hline Source: aund & & & & \\
\hline & & & & \\
\hline
\end{tabular}

Source: author's calculations.

The green energy production in Bulgaria develops in two periods: the first period is 2007-2012 and the second - after 2012. During the first period the investment process in RES starts and shows two peaks in 2010 and 2012. It coincides with the first EU programme period, availability of grants, higher feed-in tariffs, as well as introduction of obligation for the development of NREAP and municipality RES programmes. During the three year period (2007-2009) investors, financial institutions and regulating agencies got acquainted with the peculiarities of the alternative energy sources. The period is characterized with loose regulation towards the beneficiaries of feed-in tariffs, the type of the agricultural land that could be used for renewable installations, the instruments for evaluation of such investments. Some difficulties arose from the information asymmetry, the double financing and regulatory "capture" which accelerated the RES project realization especially of FV in 2012.

The second period is depicted by a restrictive renewable policy because of the additional pressure upon price by the vast number of capacities added in 2012 and increase of the independence of the state regulating agency. There was a try for political solution of the problems in the energy through introduction of a tax of $20 \%$ for wind and PV producers with the Budget Low for 2014. The tax was abrogated by the Constitution court during the same year. The achievement of the national renewable aim resulted in suspension of the feed-in tariffs, the long-term contracts and the priority of joining. The preferential conditions now are available only for small installations.

In 2012 Bulgaria succeeded to fulfill its aim of $16 \%$ share of RES, which was the plan for 2020 . The process of installation of renewable capacity differs significantly from the concrete levels envisaged in the NREAP (Table 4). 
Table 4. Forecasted and Installed RES Electricity Capacities MW

\begin{tabular}{|l|l|l|l|l|l|l|l|l|}
\hline \multirow{2}{*}{ Year } & \multicolumn{2}{|c|}{ Hydro } & \multicolumn{2}{c|}{ FV } & \multicolumn{2}{c|}{ Wind } & \multicolumn{2}{c|}{ Biomass } \\
\cline { 2 - 10 } & Planned* & Installed** & Planned* & Installed** & Planned* & Installed** & Planned* & Installed** \\
\hline 2010 & 12 & 19 & 9 & 23 & 328 & 302 & 0 & \\
\hline 2011 & 100 & 15 & 7 & 157 & 34 & 20 & 10 & 3 \\
\hline 2012 & 30 & 109 & 30 & 819 & 81 & 136 & 12 & 4 \\
\hline 2013 & 20 & 27 & 37 & 17 & 180 & 32 & 14 & 5 \\
\hline 2014 & 20 & 16 & 98 & 4 & 189 & 10 & 66 & 8 \\
\hline 2015 & 20 & 6 & 39 & 21 & 164 & 0 & 7 & 13 \\
\hline 2016 & 20 & & 13 & & 49 & & 100 & \\
\hline 2017 & 150 & & 15 & & 52 & & & \\
\hline 2018 & 30 & & 17 & & 54 & & & \\
\hline 2019 & 35 & & 18 & & 57 & & & \\
\hline 2020 & 34 & & 20 & & 60 & & & \\
\hline
\end{tabular}

Source: * Kotseva (2012)

** - Agency for Sustainable Energy Development of Bulgaria; Available at: https://portal.seea.government.bg/\#

In the NREAP the hydro, wind and PV capacities are forecasted to grow annually. There are two peeks in the installed hydro capacities - in 2011 and 2017. The FV capacities vary, as the peek was expected in 2014. The wind capacities are forecasted to develop in two periods: from 2011 till 2015 and from 2016 till 2020. The expected change of the electricity generating installed capacities on biomass is uneven - an abrupt leap in 2014 and 2016 and lack of new capacities after that, which is quite unexplainable for a forecast.

The realization of the hydropower corresponds to some extend to the plan. While the wind and biomass capacities differ significantly from the forecasts after 2013, FV development diverges from the envisaged trajectory. At the end of 2015 the achieved capacities compared to the planned is as follows:

- Hydropower: $96 \%$ fulfillment;

- FV: $476 \%$ fulfillment;

- Wind: $51 \%$ fulfillment;

- Biomass: $61 \%$ fulfillment.

At the end of 2020 it is expected Bulgaria to have 4266 MW of RES capacities, as around $60 \%$ of them to be hydro power stations and the investments in RES to be euro 3,3 billion for green electricity according to Kotseva-Tikova (2012). In 2015 the green installations were $4174 \mathrm{MW}$, as hydropower contributed with $56 \%$. The realization is $2 \%$ less capacities, while they generate enough green energy that overfills the final share.

The installed capacities differ significantly from the forecast for there was no obligation for the country to follow the path of the NREAP. The driving forces for the results achieved till 2012 were a combination of market development, available grants and feed-in tariffs, and lack of independence of the regulatory energy commission.

The fulfillment of the national 2020 renewable target is due to the abrupt installation of PV systems during the first 6 months of 2012. As a result the country ranked 10 in the top 10 PV markets in 2012 (table 5).

In 2012 the global PV market grew and about 819 MW new PV capacities were added in Bulgaria, which was a record. The high feed-in tariff of the PV electricity and the reducing price of the technology was the stimulus that enforced the private sector to execute quickly such projects, which resulted in fulfilment of the final purpose and high pressure upon the electricity price. After July 1, 2012 the feed-in tariffs were decreased significantly and the process of newly installed capacities slowed down.

The fulfillment of the 2020 target is due not only to the increase of the renewable capacity but also to the decrease of the final energy consumption in Bulgaria (Figure 6). 
Table 5. Evolution of Top 10 PV Markets

\begin{tabular}{|c|l|l|l|}
\hline Ranking & \multicolumn{2}{|c|}{2012} & \multicolumn{2}{c|}{2014} \\
\hline 1 & Germany & China & China \\
\hline 2 & Italy & Japan & Japan \\
\hline 3 & USA & USA & USA \\
\hline 4 & China & Germany & UK \\
\hline 5 & Japan & Italy & Germany \\
\hline 6 & France & UK & France \\
\hline 7 & Australia & Romania & Korea \\
\hline 8 & India & India & Australia \\
\hline 9 & Greece & Greece & South Africa \\
\hline 10 & Bulgaria & Australia & India \\
\hline & Market Level to Access the Top 10 & \multicolumn{2}{|l}{} \\
\hline & 843 MW & 811 MW & 779 MW \\
\hline
\end{tabular}

Source: IEA PVPS

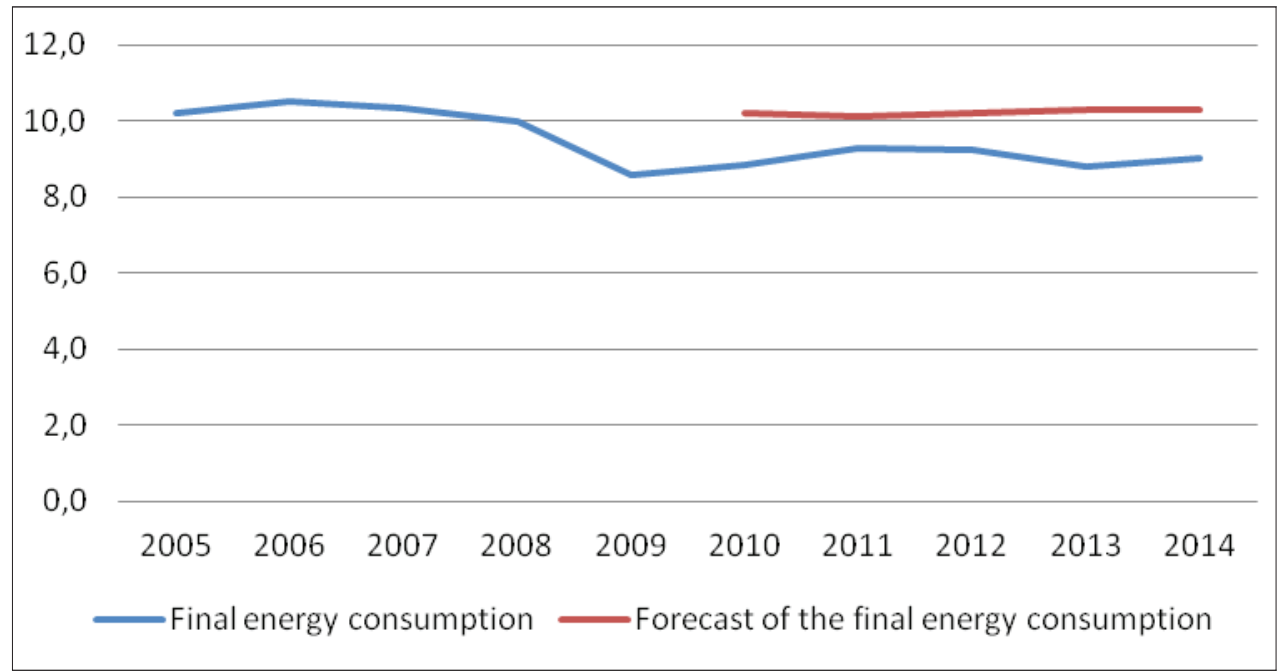

Figure 6. Final Energy Consumption (mtoe)

Source: Eurostat, June 2016, Energy datasheets: EU-28 countries; NREAP of Bulgaria

In 2014 the decrease of the final energy consumption was about $13 \%$ compared to the base 2005 . The consumption achieved was below the planned level of 10.3 mtoe, as the structure by products and sectors is depict on figures 7 and 8 .

The final energy consumption reduction is due to strong industry consumption contraction - with $35 \%$ compared to the level in 2005. In 2014 the main energy consumers were: industry - $29 \%$, transport - $34 \%$ and households $-24 \%$. The final energy consumption by products also changes. The electricity share grew to $26 \%$ or an increase by $7 \%$ compared to 2005 . The electricity consumption peaked in 2008 , decreased after that and a new increase was achieved in 2011, after which it has stabilized at that level. The gross electricity generation also changes annually (Figure 9). 


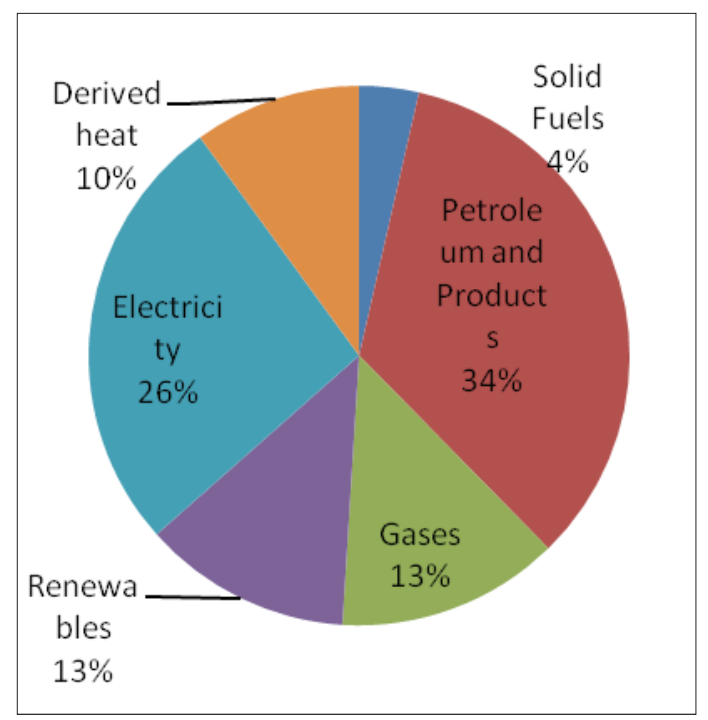

Figure 7. Final Energy Consumption by Products in 2014

Source: Eurostat, June 2016, Energy datasheets: EU-28 countries

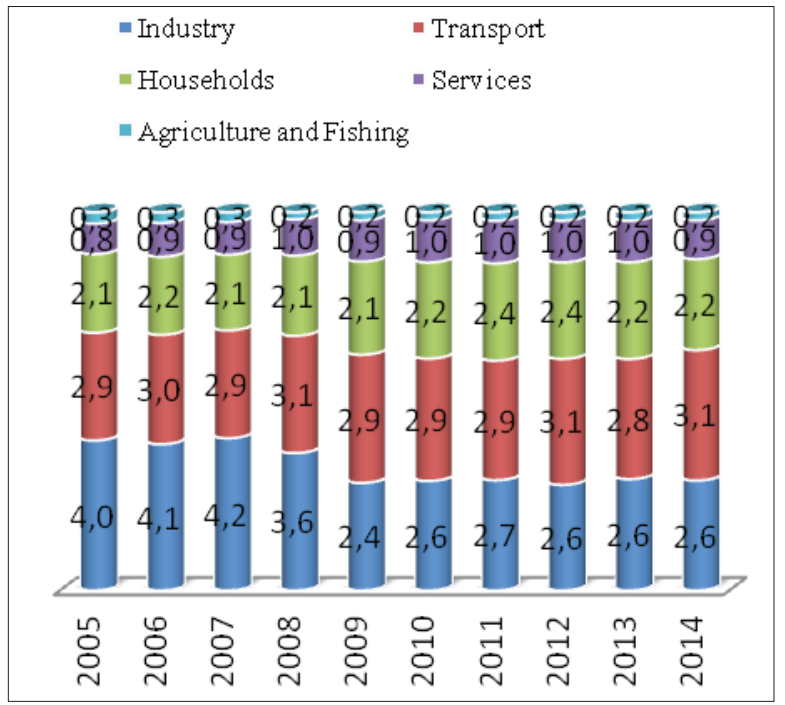

Figure 8. Final Energy Consumption by Product in 2014 (mtoe)

Source: Eurostat, June 2016, Energy datasheets: EU-28 countries

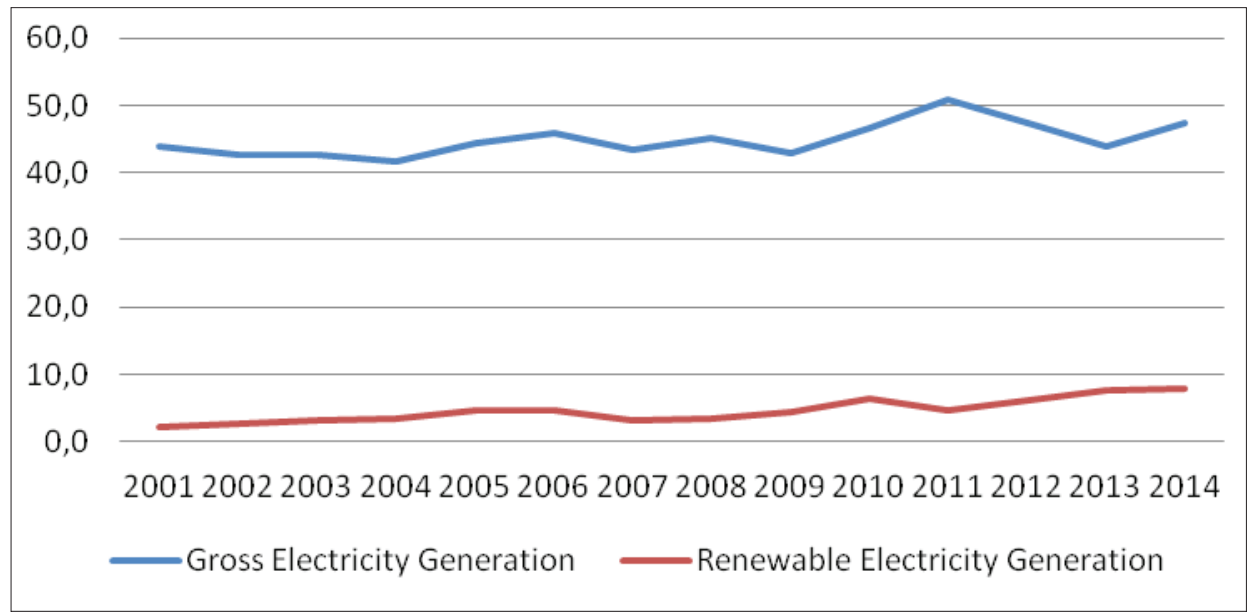

Figure 9. Gross Electricity Generation (TWh)

Source: Eurostat, June 2016, Energy datasheets: EU-28 countries

The gross electricity generation increased by $7 \%$ in 2014 in comparison with 2005 . It peaked in 2011 and decreased after it. The renewables energy grows stably as a result of the increase in the installed capacities. In 2014 their share in the gross generation reached $16.7 \%$, which was a drop in comparison with the 2013 level, when it was $17.4 \%$. The reason for such result is the smaller rate of increase of the green electricity compared with the total gross electricity generation growth in 2014.

The gross heat production changes annually (Figure 10). It peaked in 2011 and decreased slightly after that.

At the end of 2014 the heat production decreased by $4 \%$ compared to 2005 . The RES share was under $1 \%$. The main renewable source used for heating is wood and the households in Bulgaria apply it intensively - over $1 / 2$ of the households use wood for heating (Kotseva, 2013a). 


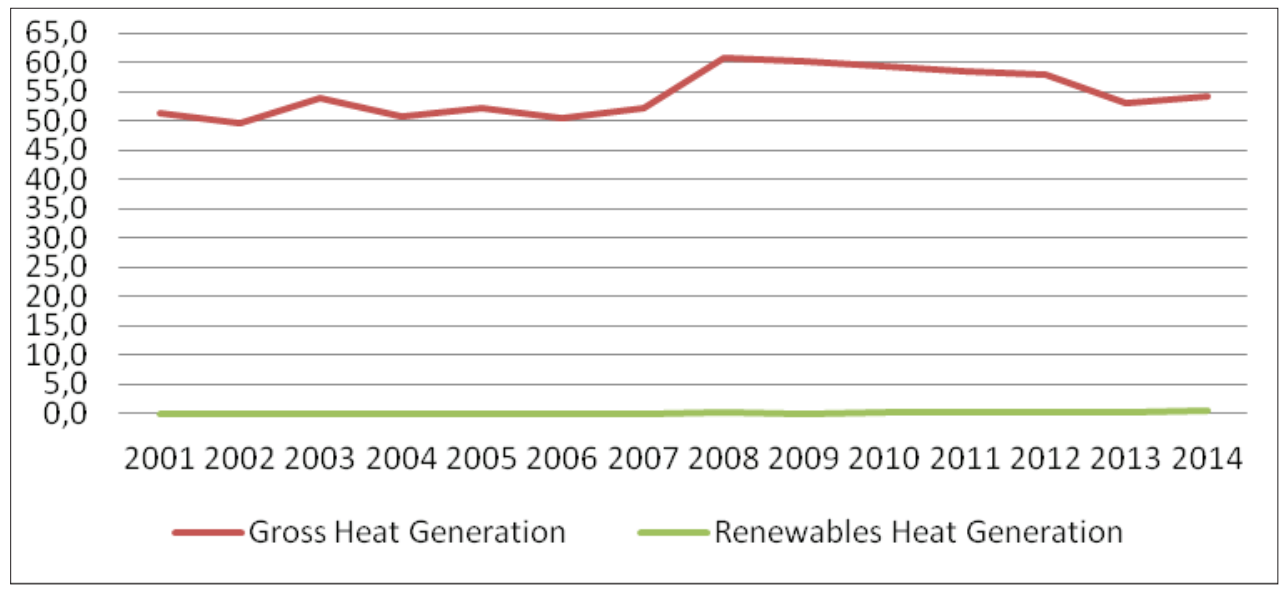

Figure 10. Heat Production (Heat Sold) - PJ

Source: Eurostat, June 2016, Energy datasheets: EU-28 countries

In the transport Bulgaria succeeded to reach a $5.3 \%$ share of biofuels in the final energy consumption in 2014. It is above the interim target which is a positive signal that the state could fulfill the aim of $10 \%$ in 2020. The main problems in the transport sector of the country are the large number of old vehicles, as well as mainly diesel engines. Over $85 \%$ of 4.1 million vehicles in Bulgaria are over 10-year old, over $43 \%$ are 20-year old, as for the last two years their number has increased by 300 thousand (from 147 to 179 thousand cars). At the end of July 2016 the electric automobiles are only 724, as $24 \%$ of them are cars. The electric cars are not spread broadly, as they are preferred as freight cars. Hybrids attract higher interest and their number is 1862 vehicles. The gas automobiles are the most preferred ecological cars and their number has increased to about 200 thousand. This makes the share of the eco-cars to be $5 \%$ of all that are registered for movement. This share is quite low in respect to the desire for limitation of greenhouse emissions. The great number of old cars and the predominantly diesel engines ( $40 \%$ of all vehicles) hamper the achievement of greenhouses emission aims.

As a result of the activities in the renewable energy sector the country has achieved very good results in respect of the quantitative targets defined (Figure 11).

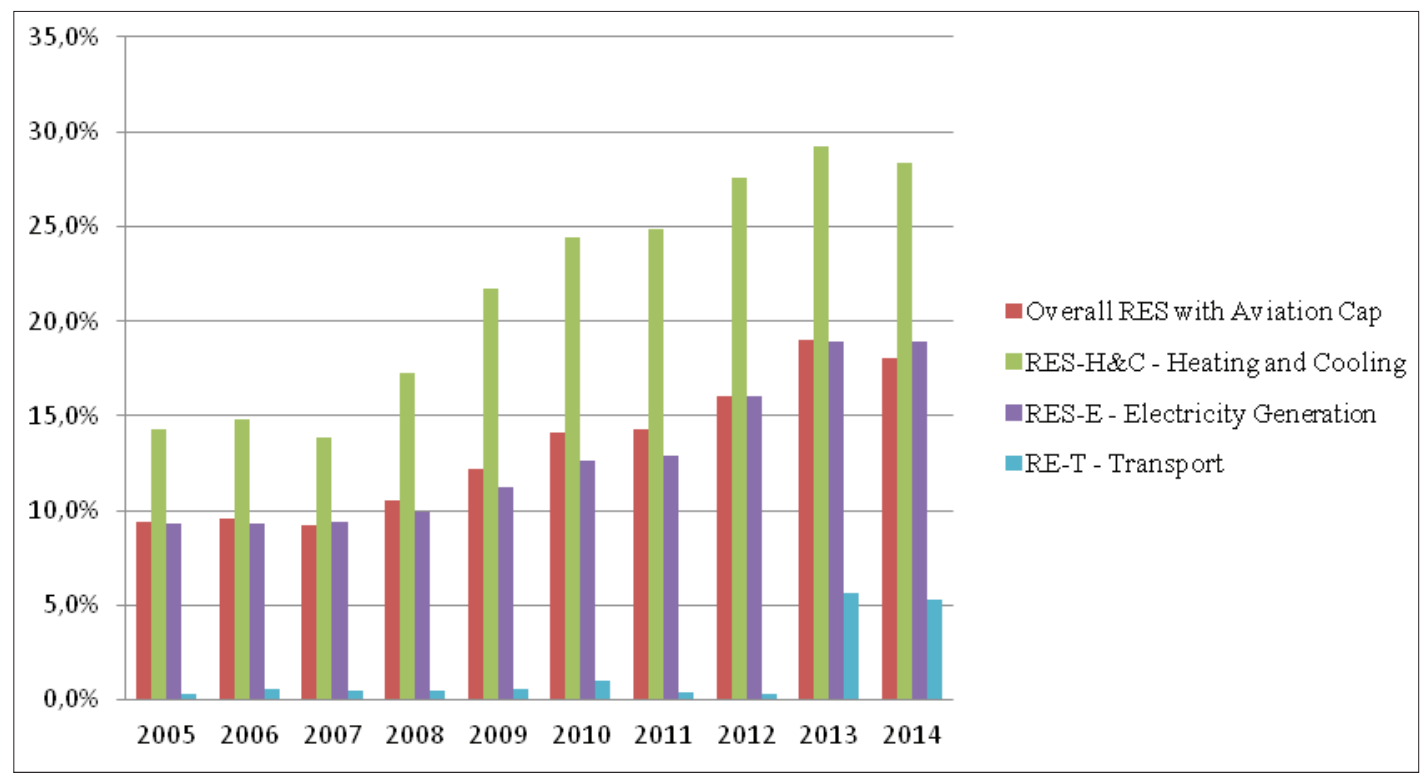

Figure 11. Renewables in Gross Final Energy (\%)

Source: Eurostat, June 2016, Energy datasheets: EU-28 countries 
The way the NREAP was executed excluded the households from the opportunity to realize benefits from the RES usage. While Germany and Japan in their renewable polices put an accent on the decentralized small-scale applications of PV modules, in Bulgaria the households have no information about the essence of the RES policy as well as have no access to grants that can stimulate a behavioral change with impact upon the increased energy efficiency and decreased dependence from foreign suppliers. The positive numbers did not bring low emissions and spur of innovations.

The greenhouse gas emissions decreased significantly but this decline cannot be quite well understood by households (Figure 12).

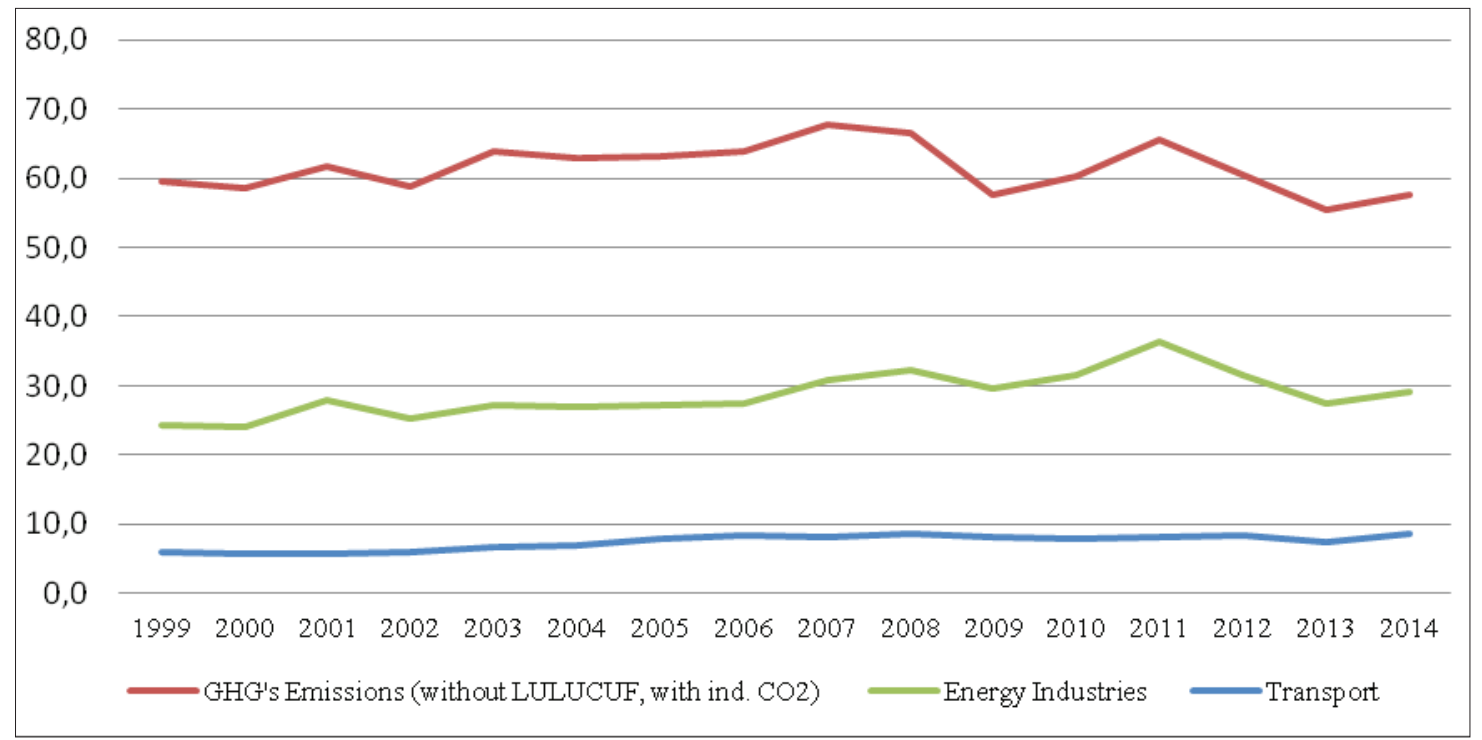

Figure 12. GHG's Emissions ( $\mathrm{mt} \mathrm{CO}_{2}$ )

Source: Eurostat, June 2016, Energy datasheets: EU-28 countries

The renewable development have not brought all the benefits that could have been reached - decentralized production by individuals, independence from monopoly energy suppliers, decrease of costs of energy, technological progress, innovations and attraction of investments, new jobs. The households use wood for heating and this is the most popular and accessible RES for $58.3 \%$ of the households (Kotseva, 2013a). They do not support the green energy alternatives - only $9.5 \%$ of the household are ready to pay more for electricity from RES (Kotseva, 2013a). Their support doubles if they receive a grant for investing in new energy sources. The analysis and evaluation of households' behavior in respect to their electricity costs, income, usage and support to RES show that the households look for and apply alternative energy sources in case of electricity prices increase and their monthly income decrease. The asymmetry of information and the lack of financing designed to motivate households to invest in renewables resulted in omitted opportunities for energy savings and for positive signals for behavioral changes. The EU evaluation of the renewable policy expected increase of the GDP and net employment creation. Such an evaluation can be more useful if it can describe the net effects for each member state, which will stimulate the RES adoption in a way that brings broad public utility and eliminate the automatic transfer of measures and targets in the national plans and strategies.

\section{Conclusion}

The fulfillment of the renewable aim is not a sign of a successful energy policy of Bulgaria. The country did not achieve the expected positive effects of a renewable policy - energy independence and decentraliza- 
tion, technology and innovation development, stable greenhouse gas decrease. The effects of the RES policy till 2012 were negative attitude to RES among the households, resulting from the corruptive practices. The households did not have the opportunity to realize environmental energy projects. They continue to use coal and woods for heating and to rely upon the utility company to supply them with the necessary electricity.

The solutions for future policy should stress upon: liberalization, implementation of good management principal in the energy sector and especially the transparency and broad participation, investment in energy technology development, efficiency, passive houses and decentralized renewable electricity generation.

The problems with green energy in Bulgaria prove that RES policies should not be considered in isolation but in conjunction with other policies and the entire strategy for economic development of the country. All the social, financial and other type of support needs reevaluation from the point of view how they contribute to emission and energy usage decrease, and to the growth of renewables application. In addition more information dissemination can be a beneficial strategy to include broader participation in the behavioral change.

\section{References}

Agency for Sustainable Energy development. Available at: https://portal.seea.government.bg/\# [visited 2016.07.06].

Awerbuc, Sh., Sauter, R. (2007). Exploiting the Oil-GDP Effect to Support Renewables Deployment. SEWPS, Paper 129. Available at: https://www.sussex.ac.uk/webteam/gateway/file.php?name=sewp129.pdf\&site=25 [visited 2016.08.24].

Awerbuch, S. (2006). Renewables Can Best Reduce the Economic Risks. New energy 2/2006 Support Renewables Deployment. SEWPS, Paper 129, p. 16-18. Available at: http://www.awerbuch.com/shimonpages/shimondocs/ Interview_neueEn_(Eng).pdf [visited 2016.08.24].

Directive 2009/28/EO of the European Parliament and the Council from 23 April 2009.

EEA. (2016). Global and European temperature. Available at: http://www.eea.europa.eu/data-and-maps/indicators/ global-and-european-temperature-3/assessment [visited 2016.08.24].

Eurostat. (June 2016). Energy datasheets: EU-28 countries. Available at: https://ec.europa.eu/energy/en/content/country-datasheets-june-2016-update [visited 2016.08.24].

Global Carbon Budget. (2015). Available at: http://www.earth-syst-sci-data.net/7/349/2015/essd-7-349-2015.pdf [visited 2016.08.24].

IEA PVP. (2015). Trends 2015 in Photovoltaic applications. Available at: http://www.iea-pvps.org/fileadmin/dam/public/report/national/IEA-PVPS_-_Trends_2015_-_MedRes.pdf [visited 2016.08.24].

Kotseva-Tikova, M. (2013a). RES and households in Bulgaria: reality and opportunities. Economic Thought, Book 1, p. 118-134.

Kotseva-Tikova, M., Mochurova-Georgieva, M. (2012). RES Usage in Bulgaria: Financial Evaluation of the EU Commitments. Institute of Economic Analysis - BAS.

Law of Energy (2015).

Member States Progress Reports. Available at: http://ec.europa.eu/energy/en/topics/renewable-energy/progress-reports [visited 2016.08.24].

National Renewable Energy Action Plan of Bulgaria. (2012). December. Available at: http://ec.europa.eu/energy/en/ topics/renewable-energy/national-action-plans [visited 2016.08.24].

The impact of Renewable Energy Policy on Economic Growth and Employment in the European Union. EC, DG Energy and Transport. (2009). Available at: https://ec.europa.eu/energy/sites/ener/files/documents/2009_employ_res_report.pdf [visited 2016.08.24].

UNDP. (2015). Global Trends in Renewable Energy Investments. Available at: http://fs-unep-centre.org/sites/default/ files/publications/globaltrendsinrenewableenergyinvestment2016lowres_0.pdf [visited 2016.08.24].

World Bank. Available at: http://data.worldbank.org/indicator [visited 2016.08.24]. 


\section{BULGARIJOS ATSINAUJINANČIOJ I ENERGETIKA ŠI UOLA I KIN I U TENDENCIJŲ KONTEKSTE}

Maria Kotseva-Tikova

Sofijos universitetas (Bulgarija)

\section{Santrauka}

Straipsnyje analizuojami Bulgarijos atsinaujinančiosios energetikos politikos igyvendinimo rezultatai ES tikslų ir globalių atsinaujinančiosios energetikos sistemų investicijų iki $2014 \mathrm{~m}$. kontekste. Politika nagrinëjama lyginant tikslus, kurie apibrèži Bulgarijos nacionaliniame atsinaujinančiosios energetikos veiksmų plane, ir pasiektus rezultatus. Rezultatai ịvertinti tiriant atsinaujinančiųjų energetikos šaltinių dalį bendrame energijos suvartojime, šiltnamio efektą sukeliančių dujų kiekị ir namų ūkio galimybes naudotis žaliaisiais energijos šaltiniais. Pagrindiniai politikos igyvendinimo padariniai yra žemas decentralizuotos energijos gamybos lygis ir gamintojų spaudimas didinti elektros kainą.

PAGRINDINIAI ŽODŽIAI: Bulgarija, klimato kaita, politika, atsinaujinančiosios energetikos šaltiniai, investicijos.

JEL KLASIFIKACIJA: Q48, Q42, Q54 